\title{
Metastatic Adenocarcinoma in the Young Adult
}

Mehta $\mathbf{M}^{1^{*}}$, Jain $\mathbf{P}^{2}$, Desai $\mathbf{M}^{3}$, Pradhan $\mathbf{S}^{4}$ and George $\mathbf{S}^{5}$

${ }^{1}$ Consultant Surgical Oncologist-Thoracic, Sir HN Reliance Foundation Hospital, Mumbai, India

${ }^{2}$ Consultant Surgical Oncologist-Colorectal, Sir HN Reliance Foundation Hospital, Mumbai, India

${ }^{3}$ Consultant Pathologist and Head of Department, Sir HN Reliance Foundation Hospital, Mumbai, India

${ }^{4}$ Chief of Oncosurgery and Consultant Surgical Oncologist, Prince Aly Khan Hospital, Mumbai, India

${ }^{5}$ Department of Histopathology, Sir HN Reliance Foundation Hospital, Mumbai, India

*Corresponding author: Mehta M, Consultant Surgical Oncologist and Thoracic, Sir HN Reliance Foundation Hospital, Mumbai, India, Tel: +61 393427000; E-mail: marzimehta1975@gmail.com

Received date: May 14, 2017; Accepted date: May 29, 2016; Published date: June 05, 2017

Copyright: (c) 2017 Mehta M, et al. This is an open-access article distributed under the terms of the Creative Commons Attribution License, which permits unrestricted use, distribution, and reproduction in any medium, provided the original author and source are credited.

\begin{abstract}
We report a case of metastatic adenocarcinoma pleura in a non-smoking 29-year-old man. X-ray Chest revealed Left sided repeated pleural effusion despite repeated tapping. CT revealed a moderate Left sided pleural effusion. A VATS biopsy of the Left Pleural Nodules and Left lung nodules revealed a metastatic adenocarcinoma. He was a non-smoker and molecular markers revealed an EGFR Mutation and were started on oral TKI. He had near complete resolution after 6 months except for mild thickening of the pleura at the base.
\end{abstract}

Keywords: Lung cancer; Adenocarcinoma; Pleural nodules; Pleural effusion; Thoracoscopic surgery

\section{Introduction}

The incidence of lung cancer among young adults has been found to be around $1.2 \%$ to $6.2 \%$ (under 40 years), $5.3 \%$ (under than 45 years) [1-4], and $13.4 \%$ (under 50 years) [5]. However, previous reports have shown trends of increasing incidence rates of lung cancer among young patients $[6,7]$.

\section{Case Presentation}

29 year old non-smoker had h/o dry cough and chest pain for 15 days.

He subsequently developed shortness of breath for 5 days. Being a Para medic, he got himself an $\mathrm{x}$-ray Chest PA view which showed moderate pleural effusion on the left side. A CT scan of the thorax and PET CT was suggestive of Nodal mass in the Left aortic pulmonary window as well as moderate left sided pleural effusion. The pleura were marginally thickened with suspicion of few nodules over the fissure.

He had h/o Tobacco chewing in small amounts for approximately 3 years but no history of tobacco smoking. No significant familial history of cancer. He was averagely built and did not have any significant Lymphadenopathy. On percussion there was a dull note in the left lower zone as well as diminished breath sounds in the left lower chest.

He was planned for a tapping of the pleural fluid and pleural biopsy via a Thoracoscopic approach (VATS-Video assisted Thoracoscopic Surgery).

The procedure was performed under General Anaesthesia with a paravertebral block [2]. Ports placed $10 \mathrm{~mm}$ and $5 \mathrm{~mm}$. A $30^{\circ}$ Telescope was used. The entire pleural cavity was visualized, which revealed, Multiple Nodules studded over lung. Parietal and visceral pleura too showed scattered nodules as well as there was extensive nodularity over the diaphragm.

Approximately $500 \mathrm{ml}$ of haemorrhagic pleural fluid drained and sent for cytology. Multiple pleural biopsies taken and sent for Frozen Section: suggestive of Adenocarcinoma. The lung expansion after the fluid drainage was adequate and hence VATS Pleurodesis done with $3 \mathrm{~g}$ of Talc. His intra operative blood loss was minimal. Chest drain was removed on 2nd Postoperative day after confirming full lung expansion on the $\mathrm{x}$-ray chest and was discharged on third postoperative day (Figure 1).
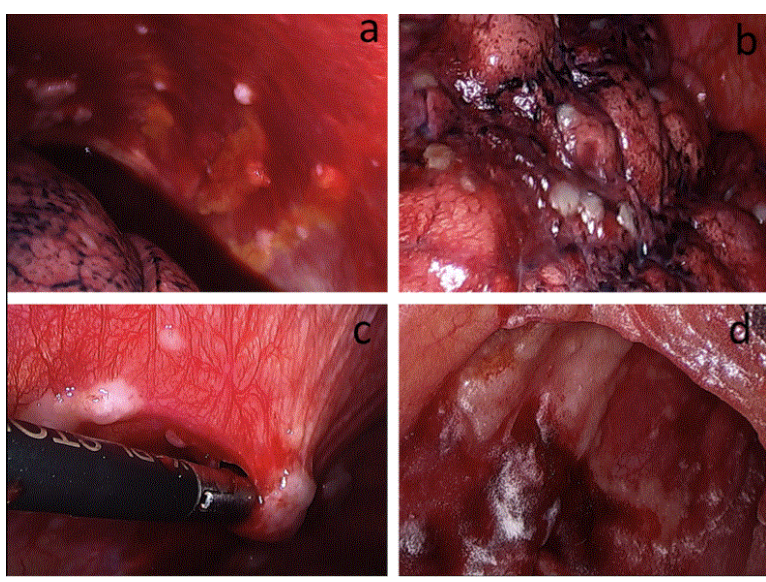

Figure 1: VATS pleural biopsy and talc pleurodesis. a) Pleural deposits with haemorrhagic effusion; b) Lung nodules; c) Pleural nodules (VATS Biopsy); and d) Talc pleurodesis.

The final histopathology on left pleural biopsy was metastatic adenocarcinoma of pulmonary origin. 
Immunohistochemistry staining shows the tumour cells strongly positive for CK-7, TTF-1 (Thyroid Transcription factor-1) and Napsin A and negative for CK-20, Calretinin, and ALK-1 (Figure 2).

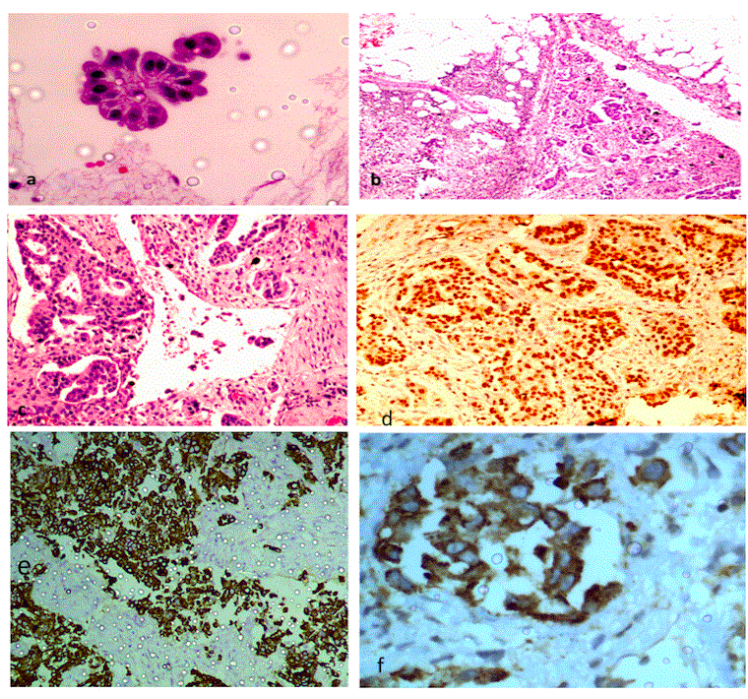

Figure 2: Final micro pictures. a) Cluster of adenocarcinoma cells in pleural fluid cell block (H and E, X100); b) Pleural biopsy with diffusely invasive malignant glands ( $\mathrm{H}$ and $\mathrm{E}, \mathrm{X} 100)$; c) Pleural biopsy with fragments of acinar malignant glands ( $\mathrm{H}$ and $\mathrm{E}, \mathrm{X} 100)$; d) Malignant glands with (Thyroid Transcription factor-1) immunoreactivity (TTF-1, X100); e) CK-7 positivity in tumor cells (X100); f) Napsin A positivity in tumor cells seen as brown granularity in the cytoplasm (X400).

His molecular testing revealed EGFR mutation positive on Exon 19 and was subsequently started on oral TKI. He had a good response within 6 months of initiating the treatment and is disease free till date.

\section{Discussion}

Lung cancer in young adults has several unique characteristics: a high percentage of patients are female, more adenocarcinoma, and more advanced stage at the time of diagnosis, and more patients receiving aggressive treatment [8-11]. Previous studies have shown that young patients had a similar survival as older patients [12]. In contrast, some studies have reported that younger patients have better outcomes $[13,14]$. These inconsistent findings could be related to different treatment modalities and ethnicities of patients.

Although it is easy to assume that the recurrent pleural effusion in the elderly smoker could be malignant, it is extremely difficult to assume the same in the young adults. It is important to note that, even in young adults, if there is recurrent pleural effusion and a cause is not determined, it would be worthwhile considering a Video Assisted Thoracoscopic procedure (VATS) for these individuals.

Thoracoscopy (under sedation or general anaesthesia) has grown in popularity as a diagnostic and therapeutic tool for malignant effusions. Under sedation, it is now widely used by respiratory physicians in the diagnosis and management of pleural effusions in patients with good performance status. Patient selection for thoracoscopy and talc poudrage is important in view of the invasive nature of the procedure and cost. A significant benefit of thoracoscopy is the ability to obtain a diagnosis, drain the effusion and perform a pleurodesis during the same procedure. The diagnostic yield and accuracy of thoracoscopy for malignant effusions is $>90 \%$ [15]. Talc poudrage performed during thoracoscopy is an effective method for controlling malignant effusions with a pleurodesis success rate of $77-100 \%$. Randomised studies have established the superiority of talc poudrage over both bleomycin and tetracyclines.

Thoracoscopy has less to offer in patients with a known malignant pleural effusion and a clearly trapped lung on the chest x-ray. However, under general anaesthesia, reinflation of the lung under thoracoscopic vision will inform whether the lung is indeed trapped and therefore guide the decision to perform talc poudrage or insert a pleural catheter. The procedure can facilitate breaking up of loculations or blood clot in haemorrhagic malignant pleural effusion and can allow the release of adhesions and thereby aid lung re-expansion and apposition of the pleura for talc poudrage.

Thoracoscopy is a safe and well-tolerated procedure with a low perioperative mortality rate $(<0.5 \%)$. The most common major complications are empyema and acute respiratory failure secondary to infection or re-expansion pulmonary oedema; although the latter may be avoided by staged evacuation of pleural fluid and allowing air to replace the fluid.

The frequency of EGFR mutation in adenocarcinoma showed wide variation among different reports (3-59.7\%); this was related to ethnicity, gender, and smoking status [16-20]. Several studies, in which East Asia was the focus, have shown that the EGFR mutation rate in NSCLC was about $26-38.6 \%$, and the mutation rate increased $32-55 \%$ in adenocarcinoma [16-18]. However, there is a paucity of data regarding the EGFR mutation status in young patients (Figure 3).

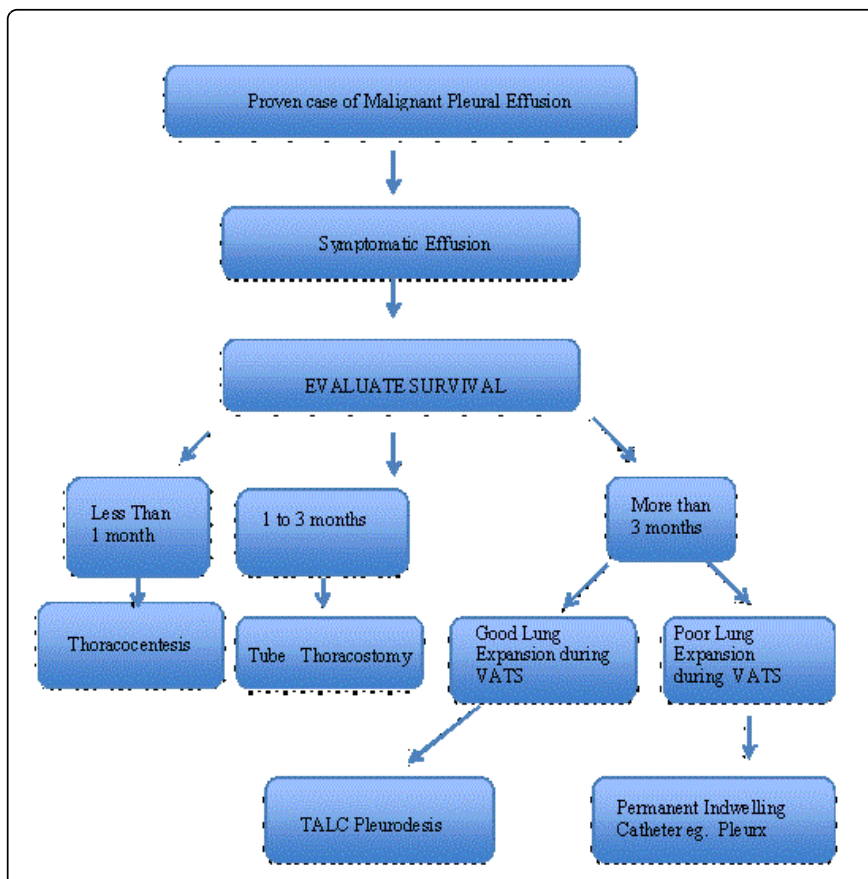

Figure 3: Management of malignant pleural effusion. 
Citation: Mehta M, Jain P, Desai M, Pradhan S, George S (2017) Metastatic Adenocarcinoma in the Young Adult. Arch Surg Oncol 3: 125. doi:

Page 3 of 3

\section{Conclusion}

Metastatic Adenocarcinoma of the Lung with involvement of the pleura along with repeated pleural effusion is commonly encountered in the elderly with history of smoking. This case report however highlights the importance of having a high index of suspicion, which enabled us to pick up the correct pathology and treat accordingly.

Recurrent pleural effusion for which a cause cannot be ascertained should be followed up with imaging and VATS pleural biopsy should be a part of the algorithm.

\section{References}

1. Zhang J, Chen SF, Zhen Y, Xiang J, Wu C, et al. (2010) Multicenter analysis of lung cancer patients younger than 45 years in Shanghai. Cancer 116: 3656-3662.

2. Subramanian J, Morgensztern D, Goodgame B, Baggstrom MQ, Gao F, et al. (2010) Distinctive characteristics of non-small cell lung cancer (NSCLC) in the young: a surveillance, epidemiology, and end results (SEER) analysis. J Thorac Oncol 5: 23-28.

3. Kuo CW, Chen YM, Chao JY, Tsai CM, Perng RP (2000) Non-small cell lung cancer in very young and very old patients. Chest 117: 354-357.

4. Liam CK, Lim KH, Wong CM (2000) Lung cancer in patients younger than 40 years in a multiracial Asian country. Respirology 5: 355-361.

5. Ak G, Metintas M, Metintas S, Yildirim H, Erginel S, et al. (2007) Lung cancer in individuals less than 50 years of age. Lung 185: 279-286.

6. Strand TE, Malayeri C, Eskonsipo PK, Grimsrud TK, Norstein J, et al. (2004) Adolescent smoking and trends in lung cancer incidence among young adults in Norway 1954-1998. Cancer Causes Control 15: 27-33.

7. Marugame T, Yoshimi I, Kamo K, Imamura Y, Kaneko S, et al. (2005) Trends in lung cancer mortality among young adults in Japan. Jpn J Clin Oncol 35: 177-180.

8. Chen KY, Chang CH, Yu CJ, Kuo SH, Yang PC (2005) Distribution according to histologic type and outcome by gender and age group in Taiwanese patients with lung carcinoma. Cancer 103: 2566-2574.
9. Capewell S, Wathen CG, Sankaran R, Sudlow MF (1992) Lung cancer in young patients. Respir Med 86: 499-502.

10. Skarin AT, Herbst RS, Leong TL, Bailey A, Sugarbaker D (2001) Lung cancer in patients under age 40. Lung Cancer 32: 255-264.

11. Bourke W, Milstein D, Giura R, Donghi M, Luisetti M, et al. (1992) Lung cancer in young adults. Chest 102: 1723-1729.

12. Zou B, Xu Y, Li T, Li W, Tang B, et al. (2010) A multicenter retrospective analysis of survival outcome following postoperative chemoradiotherapy in non-small-cell lung cancer patients with N2 nodal disease. Int J Radiat Oncol Biol Phys 77: 321-328.

13. Radzikowska E, Roszkowski K, Glaz P (2001) Lung cancer in patients under 50 years old. Lung Cancer 33: 203-211.

14. Ramalingam S, Pawlish K, Gadgeel S, Demers R, Kalemkerian GP (1998) Lung cancer in young patients: analysis of a Surveillance, Epidemiology, and End Results database. J Clin Oncol 16: 651-657.

15. Mack MJ, Aronoff RJ, Acuff TE, Douthit MB, Bowman RT, et al. (1992) A Present role of thoracoscopy in the diagnosis and treatment of diseases of the chest. Ann Thoracic Surg 54: 403-409.

16. Paez JG, Janne PA, Lee JC, Tracy S, Greulich H, et al. (2004) EGFR mutations in lung cancer: correlation with clinical response to gefitinib therapy. Science 304: 1497-1500.

17. Huang SF, Liu HP, Li LH, Ku YC, Fu YN, et al. (2004) High frequency of epidermal growth factor receptor mutations with complex patterns in non-small cell lung cancers related to gefitinib responsiveness in Taiwan. Clin Cancer Res 10: 8195-8203.

18. Kim YT, Kim TY, Lee DS, Park SJ, Park JY, et al. (2008) Molecular changes of epidermal growth factor receptor (EGFR) and KRAS and their impact on the clinical outcomes in surgically resected adenocarcinoma of the lung. Lung Cancer 59: 111-118.

19. Mok TS, Wu YL, Thongprasert S, Yang CH, Chu DT, et al. (2009) Gefitinib or carboplatin-paclitaxel in pulmonary adenocarcinoma. N Engl J Med 361: 947-957.

20. Rosell R, Moran T, Queralt C, Porta R, Cardenal F, et al. (2009) Screening for epidermal growth factor receptor mutations in lung cancer. N Engl J Med 361: 958-967. 